\title{
Participant Structure in Learning English: Linguistic Anthropology Approach
}

\author{
Tasnim Lubis \\ LP3I Polytechnic Medan \\ Medan, North Sumatera, Indonesia \\ tasnimlubis@yahoo.com
}

\begin{abstract}
Studying about students' participant structure in learning English has important role in evaluating their character toward implementing a method or technique further. To figure out their participant structure, the researcher used linguistic anthropology approach. It is able to provide information about students' participation verbally and non-verbally. The objective of the study was to describe students' participant structure in learning English. Participant structure theory which is proposed by Philip (1972) was applied in this study. Qualitative method was implemented in this study. The location of study was in LP3I Polytechnic Medan at Sei Serayu street number 48D. The data were recordings of students' participant in classroom during studying English by using handycam Panasonic FULL HD. Besides, interview and observation also used to support recording. They were analyzed by using interactive model analysis that consist of data selection, data display, and verifying/conclusion. Data selection noticed the performance, indexes, and participation which refer to participation during learning in classroom. Data display described the participant structure during learning in the classroom. Verifying/conclusion explained about the dominant participant structure in the classroom during learning English. The result of the study showed that participant structure of student in LP3I Polytechnic Medan was involving the entire classroom interaction or type I. It is occured because all students need to be involved and to be given attention by lecturer to overcome their problem in learning English such as lack of confidence and afraid to make mistake in their speech.
\end{abstract}

Keywords-participation structure; learning English; anthropolinguistics; LP3I Polytechnic Medan

\section{INTRODUCTION}

Some says that the favorite question among teachers or lecturers is 'any question?' and the favorite answer among students is "no". No is not just a common simple answer among students. The meaning behind no is more than that word. When I interviewed some students about it, no represented many meaning such as I am ashamed to say yes, or I don't understand at all, or I want to ask the part that I don't understand, but maybe later on. A good lecturer should know and able to manage the classroom in order to have a good learning process. Participation type is one of the element toward the learning success. To find out the type, a lecturer should pay attention to the participation of students in classroom. The participation can be observed from their performance. The study of participant performance is important because it is able to describe and/or display a production of utterances which can be observed [1]. The describing or displaying is a pattern of a participant performance. Further, it will be a data to determine appropriate model, strategy, or technique to apply in teaching.

The objective of the study was to investigate the participation model through participation structure in learning English at LP3I Polytechnic Medan. This study contributeses in giving information and provide evaluation toward appropriate strategy or technique in teaching English. At LP3I Polytechnic Medan, the ability of speaking English is an supplement competence besides students' main competence that should be owned because link and match to the workplace further. The adequate method or technique in teaching English will build the students' confidence to participate in learning, therefore they are able to catch the learning and the objective of learning will be achieved. To reach the mission and vision especially in facing the challenge of MEA/ASEAN Economic Community in Indonesia, LP3I Polytechnic Medan should have a good effort in building a good situation for education. Students should be able to communicate in English as international language toward facing the condition [2].

\section{LITERATURE REVIEW}

Teaching English has its own challenges. But, even though a lot of problems in teaching, it is must be related to the motivation both intrinsic and extrinsic. The factor that influence students in finishing their vocabulary pocket book assignment namely daily English vocabulary in LP3I Polytechnic Medan are deixis, discipline, and intrinsic motivation [3]. In addition, they do not want to practice their because they were shy and afraid to make mistake in speaking in English.

The concept of participation in this study covered the deliberation of speech community. Participation is an important dimension and also an approach to study about speech community [4]. Structure participation is understood as a certain type of a structure framework in an interaction [4]. He determined structure participation in four types, they are type I, type II, type III, and type IV. Type I deliberates the entire students to interact with the teacher. This type focuses on a student to do his/her work like show and tell. In this type, all students have a turn to talk. Type II only deliberates a small group of students to interact with the teacher, while others focus on their work. Type III deliberates each of students to interact with teacher. Type IV is different from the three, it 
asks students to do their work on paper work. For example, Indian students prefer to ask the questions more than the other students as a response of their teacher. Beside asking the question to their teacher, they also like to ask the question to their friends. Philips also there was a contrast way to interact with Indian adult and children to non-Indian teacher [4].

The advantage of knowing a participant structure in teaching process is to provide information to be evaluated. Teacher/lecturer will be able to determine the appropriate type to be used in learning process. Finding a structure participant in classroom is one of skill that have by lecturers as a facilitator. Teaching is not an easy thing to do, but it is an important one. It will be something worth full and when teachers see and observe that there is their role in making students improve in their learning process. It is obvious sometimes some lessons and students make teachers stress, but on the other side, when teachers found the best way for the to teach, it will fun and they will enjoy it [5]. I myself can say teaching is fun and enjoy and there is no word "but" as long as able to find the way how to solve the problem in the classroom. Problem such as noisy, lack of motivation, difficult to focus will be able to be solved. The First step is teachers/lecturers have to know the participation structure.

\section{METHOD}

This is a qualitative study. Linguistic anthropology approach was used to have a holistic result because it rely on speech and act in participation structure. The object of this study was participant structure of learning English in classroom. The data were students' performance which is taken from recording of activity in classroom through CCTV and handycam Panasonic FULL-HD. Besides audio-video recording, observation and interview also used as the technique to collect the data. Observation used to observe the pattern of interaction in action. Interview used to support the data from the observation. Data were analyzed by using Miles, Huberman, \& Saldana analysis which covered data reduction, data display, and verification/conclusion [6].

\section{RESULT AND DISCUSSION}

The result of data reduction displayed that students participate when their turn to participate was coming. It can be seen when teacher gave opportunity to participate voluntary, they looked each other which means giving the opportunity to their friends. It is indexed to the Indonesian culture the characteristic to show politenes. Sometimes, several students who really aware that she/he able to participate, they would come to take a part. For example, when lecturer did brainstorming at the beginning of the lesson. Before teaching describing, the lecturer asked the students to describe their feeling at that morning. The text can be seen below:

$\begin{array}{lll}\text { Dosen } & : & \text { Please give me one word to describe about this morning } \\ \text { Student1 } & : & \text { Cold } \\ \text { Student2 } & : & \text { Great } \\ \text { Student3 } & : & \text { Good } \\ \text { Student4 } & : & \begin{array}{l}\text { Not too bad (eh lebih dari satu kata ya Ms?/eh more } \\ \text { than one word Ms?) }\end{array} \\ \text { Dosen } & : & \begin{array}{l}\text { Yeah... but it's okay. Not too bad is consists of three } \\ \text { words, but it has one meaning right? }\end{array}\end{array}$

From the text above, it can be seen students really afraid to make mistake when they used English. In learning English at the first meeting, lecturer often noted that students feel and think that English is difficult. It is noted that they seem denied to learn English due to some reasons such as do not think that English is important to learn, or they have unpleasant experience in learning English while in Senior High School. Data recording displayed students in the classroom sit in letter $\mathrm{U}$ form. It is an order from the lecturer because the form makes her easier to walk through and get closer to the students. The form began at the second meeting. From the second meeting until at the last meeting (except midterm and final exam), they like to sit constantly. They sit in two rows and they did not like to move from one side to another side. Just a few of them like to move but only from the first row to the second row.

From interview result, student did not have problem with the form of sit. They did not do response directly, because they wait each other to response or answer lecturer's question. They also admitted that they prefer to be pointed by lecturer to answer or respond. It means they have their own territory to participate. The interview result supported observation from the researcher. When lecturer asked question or only confirmed, they did not response immediately. Lecturer had to wait for few minutes and after that decided to ask one of them to participate and that is the way go along.

\section{A. Data selection}

From all recording, the data focus on participation structure while learning process. The lesson began with giving motivation by a student who had turn to do that. There were several techniques applied in the learning process such as group work, individual task, and problem based learning. In all of the techniques, the participate structure still stay in one pattern, it is type I. $70 \%$ of them must be asked to participate instead of waiting for their turn taking.

\section{B. Data display}

From the three of recordings, during learning, there were $30 \%$ students who did participate by interact with lecturer. The others were waiting for the turn taking. The 30\% students were able to speak and also had good self confidence. Therefore, they like to participate by answer and ask question. For the others, lecture had to called their names and sometimes gave them the time to do participation.

\section{Verification}

Through linguistic anthropology approach, the performance of students and lecturer in classroom during learning process indexed to the character of Indonesian in common. But, it is not only indexed in positive character such as politeness, it is also indexed to saving face. Face, or reputation, as "the positive social value a person effectively claims for himself by the line others assume he has taken during a particular contact. Face is an image of self delineated in terms of approved social attributes" [7].

The presence of linguistic anthropology related to language as a source of culture and speaking as a cultural practice. It helped this research to obtain complete results, 
because language is part of human behavior [4]. Research on human language is not only in the realm of speech produced, but also in how the speech is produced. Language use is fundamentally multimodal (multi-expression) [8].

\section{CONCLUSION}

Refer to Philips types of participation structure, learning English at LP3I Polytechnic Medan was type I. It was able to observed from their performance in recording like they were waiting for their turn to participate. Students needed to be paid attention in order to build their self confidence. Despite of several students had already have good self confidence and wanted to participate, but it was also have negative effect to the others students like they felt ashamed because they thought that they did not able to be looked good as their friends. In this case, lecturer deliberated all of them in interaction toward building their self confidence and making them sure that every student has opportunity to participate during learning in the classroom.

\section{REFERENCES}

[1] T. Lubis, "PERFORMANSI PARTISIPASI PEMBELAJARAN BAHASA DI POLITEKNIK LP3I MEDAN," Basastra J. Kaji. Bhs. dan Sastra Indones., vol. 8, no. 1, pp. 70-87, 2019.

[2] T. Lubis and Syahril, "Students' Reading Ability toward TOEIC Score," in Seminar Nasional Industrialisasi Madura, 2015, pp. 1-8.

[3] T. Lubis, "Faktor yang Mempengaruhi Kesulitan Mahasiswa dalam Menyelesaikan Daily English Vocabulary,” J. Bisnis Adm., vol. 06, no. 1, pp. 29-36, 2017.

[4] A. Duranti, Linguistic Anthropology. New York: Cambridge University Press, 1997.

[5] J. Harmer, How to Teach English, New Editio. China: Pearson Education Limited, 2010.

[6] M. B. Miles, A. M. Huberman, and J. Saldana, Qualitative Data Analysis: A Methods Sourcebook. Thousand Oaks: SAGE Publications, Inc, 2014.

[7] E. Goffman, Interaction Ritual: Essays on Face-to-face Behaviour. New York: Pantheon Books, 1967.

[8] M. Seyfeddinipur and M. Gullberg, Eds., From Gesture in Conversation to Visible Action as Utterance. Amsterdam/Philadephia: John Benjamin Publishing Company, 2014. 